\title{
Assessment of Coastal Resort Development: The Case of Lebanon
}

\author{
Said M. Ladki, Patrick El Meouchi \\ Lebanese American University, Beirut, Lebanon
}

\begin{abstract}
This research investigates the relationships between illegally built resorts along Lebanon's shoreline and beach goers' right to access public beaches for free. The study was conducted by students at the Lebanese American University. Sample $(n=255)$ participants agreed to participate in this study. Pearson correlation and stepwise regression analysis results indicated significant relationships $(p \leq 0.05)$. Five hypotheses were tested, and four of which were accepted. The development of free public beaches is undoubtedly correlated with the illegally existing resorts along the coast. If illegally built resorts were to be legalized, communities may have free access to developed public beaches. The purpose of this research is to investigate the relationships between illegally built resorts along Lebanon's shoreline and beach goers' right to access public beaches for free. Beach goers' opinions and attitudes towards public beaches are also investigated.
\end{abstract}

Keywords: Lebanon, resort, development, public beaches

\section{Introduction}

During the Lebanese civil war (1975-1991), numerous marinas, beach resorts, hotels, and industrial complexes with beach access were illegally built along the Mediterranean. Though Lebanon's coastline alternates between sandy beaches $(15 \%)$ and rocky beaches $(85 \%)$, all of the developments have taken place along the sandy beaches. The developments of such resorts and hotels prevented the local people from having access to free public beaches. In the very few cases where access is granted, resorts require beach goers to pay high entrance fees which were beyond the economic means of local community residents.

In Lebanon, neither the local nor the central governments monitor or regulate the use of the coastline. All mega resorts, marinas, and other coastal development projects were built without obtaining the appropriate governmental approvals and permits. Coastal development investors have financially benefited and illegally taken advantage of available natural resources. If the illegal conditions were to be changed to legal ones, resort operators will be compelled to pay hefty fines to the government in order to settle their illegal status. This will generate revenues for the treasury while simultaneously achieving the following two objectives: (1) developing the coast while meeting environmental and constitutional codes; and (2) providing the public with the right of accessing sandy beaches for free.

The development of coast and public beaches is considered as an important contributor to Lebanon's tourism industry, as well as being a significant potential revenue generator. Lebanon's 150 miles coastline is

Said M. Ladki, Ph.D., interim dean, School of Business, Lebanese American University. Email: sladki@lau.edu.lb. Patrick El Meouchi, MBA, School of Business, Lebanese American University. 
dotted with numerous illegally built beach resorts and water front communities that serve local and international beach lovers. The resorts offer interesting varieties of seaside activities, enabling them to be ranked among the top tourism generators in Lebanon. However, the government is not displaying an active role in the management of the coastline. Community residents are not provided with free access to sandy beaches. Moreover, the government lacks needed funds to develop free access public beaches with high-end services. Currently, the government is focusing on other sectors that it considers as more functional to the Lebanese economy, mainly the banking sector.

Many other forces contribute to the low demand for public beaches in Lebanon. The most important is the limited availability of sandy beaches along with the inferior level of services and infrastructures. Public beaches do exist, but in limited areas, and they are usually found in dreadful conditions. Other reasons include negative attitudes towards public beaches because of the assumption that they are frequented by lower income groups. Moreover, environmental issues such as locating landfills along the beach, dumping of sewage, and chemicals further decrease the demand for public beaches. Another environmental concern surfaced after the July 2006 war, when the Israeli fighter jets raided Lebanon's southern power plant, resulting in 15,000 ton oil spill (Aboudehn, 2007).

\section{Literature Review}

\section{Tourism in Lebanon}

Lebanon is considered as an attractive destination for international tourism. In addition to the great weather and beautiful mountains, the country boasts diverse cultural, entertainment, and ancient historical sites. Despite Lebanon's political turmoil and instability, the country welcomed over two million tourists in 2010. Lebanon enjoys a reputation for being a major regional attraction. Concerts (Shakira, Eminem, etc.), festivals (Baalbek, Byblos, and Beiteddine), fashion shows (Louis Vuitton, Christian Louboutin, and Balenciaga), and special events like dance and beach parties are held on a monthly basis.

Marinas and resorts are located in various municipalities along the shoreline like Jounieh, Maameltein, Khaldeh, Damour, Rmeileh, and Tyre; all serve as one of the main seasonal attractions during summer months. According to the Lebanese Ministry of Tourism (2007), eight marinas exist in Lebanon along the entire length of the country from north to south. There are 23 legally built and eight illegally built beach resorts and marinas in Lebanon (Lebanese Ministry of Tourism, 2007), meaning that, about 34\% of the resorts built along the shoreline are illegally built. This figure does not include hotels and motels with swimming pools built on the coast. In the bay of Jounieh as well as the shore of Maameltin and Zouk, more than 14.5 million $\mathrm{ft}^{2}$ have been converted into exclusive resorts (Zbeeb, 2012b).

\section{Public Beaches in Lebanon}

Public beaches with free access are available in different Lebanese cities: Ramlet el Bayda public beach (Beirut), Tyr public beach (Tyr, south of Lebanon), Sidon public beach (Sidon, south of Lebanon), and Tripoli public beach (Tripoli, north of Lebanon). Currently, there are seven development project initiatives designed to create new public beaches with free access.

Beaches' clean-ups are regularly practiced. However, the clean-ups are planned and implemented by volunteers, environmental groups, and organizations with little or no support from the government. The clean-up of Tyr public beach was led by environmental volunteers and universities' social clubs whose efforts 
have encouraged locals to visit more often. For those involved in the development of public beaches, it is essential to get local communities involved in project development, environmental campaigns, maintenance, and the upkeep of the beach.

The concept of public beaches is well known all around the world. In many countries, free access to public beaches is considered as a right to the public and tourists as well. For example, Malaysia and Brazil through their Ato das Disposicoes Constitucionais Transitorias ${ }^{1}$ (Act of the Transitory Constitutional Arrangements) stated that there is a free access to the national territory in time of peace, permitting any person having a legal status to enter, stay, or leave according to his/her desires. Similarly, Greece offers free public access to beaches. In the United States, Coastal Zone Management proved to be successful when coast development for recreational purposes granted free access to all (Pogue \& Lee, 1999).

According to Pogue and Lee (1999), the locals will be ready to embrace the plan to develop their coast once they are well informed. Involvement of locals can be through memberships in non-profit organizations which could create positive social, economic, and environmental impacts. Members of some societies were so involved in the development of their coast that they became stewards of a critical piece of coastal property and partnered with other non-profits. "They have now become the new guardians of their local coastal area" (Pogue \& Lee, 1999, p. 232).

\section{Illegally Built Projects on Public Beaches}

A study prepared by the Ministry of Public Works and Transport reported that illegally built resorts have occupied coastal properties along the 49,212,500 $\mathrm{ft}^{2}$ Lebanese coastline (Assaf, 2009).

An extensive list identifying all illegally built establishments across industries was developed. The list includes: industrial complexes, warehouses, manufacturing facilities, resorts, and others. Since the main objective of this research focuses on the tourism industry, the names of some of the illegally built resorts and coastal development facilities that are located throughout Lebanon and that occupy illegal beach surface areas are reported in Table 1.

Table1

Lebanese Hospitality Firms Illegally Occupying the Coast

\begin{tabular}{lll}
\hline No. & Name of the establishments & Illegally occupied surface \\
\hline 1 & Automobile et Touring Club du Liban (ATCL) & $373,919 \mathrm{ft}$. \\
2 & Naser for tourism & $314,960 \mathrm{ft}$. \\
3 & Halat Sur Mer & $281,856 \mathrm{ft}$. \\
4 & Neptune for tourism & $281,856 \mathrm{ft}$. \\
5 & Holiday Beach (Kesrwan) & $164,999 \mathrm{ft}$. \\
6 & Tabarja Beach & $131,233 \mathrm{ft}$. \\
7 & Golden Beach & $62,335 \mathrm{ft}$. \\
8 & Costa Brava & $52,329 \mathrm{ft}$. \\
\hline
\end{tabular}

A report by the Ministry of Public Works and Transport has identified all unlicensed encroachments on the Baabda and Chouf beachfronts, totaling 143 cases. Through kick-backs and favoritism, unscrupulous investors have obtained permits to construct properties along the beach. The violators have seized a total of 3,532,862 $\mathrm{ft}^{2}$ of public beachfront property, mostly from reclaiming the sea. Examples of two illegally built facilities through

\footnotetext{
1 Article 4, Chapter XV, Ato das Dispoicoes Constitucionais Transitorias (Act of the Transitory Constitutional Arrangements), Brazil.
} 
what is known as unconstitutional presidential executive orders are the family beach and Summerland beach. Family beach was granted an executive order to reclaim $8,998 \mathrm{ft}^{2}$ of sea. Instead, they reclaimed 175,537 $\mathrm{ft}^{2}$, grabbed more than $38,900 \mathrm{ft}^{2}$ of water surface, and constructed facilities on public property amounting to around 23,680 $\mathrm{ft}^{2}$. Likewise, the Summerland Hotel, which was awarded an executive order to reclaim $333,141 \mathrm{ft}^{2}$ of sea, develop 127,659 $\mathrm{ft}^{2}$ of the water surface, and build installations on 127,659 $\mathrm{ft}^{2}$, reclaimed $460,413 \mathrm{ft}^{2}$, seized 152,954 $\mathrm{ft}^{2}$ of water surface, and built installations on 46,284 $\mathrm{ft}^{2}$ (Zbeeb, 2012a).

Currently, there is no law requiring beach resort operators to pay any kind of settlements and change their status to a legal one. If a change of status from illegal to legal is to be legislated, resorts will be required to make a financial settlement with the government. The amount of each settlement will depend on the land value per square foot in the community in which the resort is built. Otherwise, resorts will have to be removed completely, and their owners will be forced to pay hefty fines.

\section{Methodology}

\section{Procedure}

This research investigates the relationship between illegally built resorts along Lebanon's shoreline and beach goers' right to freely access public beaches. Beach goers' opinions and attitudes towards public beaches were also investigated. Data were collected by a survey distributed to beach goers in Lebanon.

\section{Sample}

The research required respondents to answer questions concerning their opinions and attitudes towards the development of public beaches along with consumer visitation frequencies. The sample represented undergraduate and graduate students, environment club members, and beach lovers. Most of the respondents were students at the Lebanese American University.

\section{Instruments}

Items on the questionnaire were designed to measure respondents' opinions and attitudes towards public beaches and their degree of involvement in public beaches' development initiatives. The questionnaire was composed of three parts: (1) public opinion and awareness; (2) public involvement; and (3) socio-demographics. Except for demographic variables, all the other items on the survey were answered on a 5-point Likert type scale.

The Likert scale asked respondents to rate their agreement or disagreement ranging from $1=$ strongly disagree to $5=$ strongly agree. Other items, "what would be the reason for not visiting public beaches: image, people, location, and absence of service facilities" and "I would rather go to a public beach if well developed" or "I only visit private beach in any case" were answered by checking a box of possible options.

\section{Research Hypotheses}

Five hypotheses are to be tested in this research:

H1: There is a relationship among beach goers, socio-demographics, and the visitation of public beaches.

$\mathrm{H} 2$ : There is a relationship between local community involvement in beach development and visitations of public beaches.

H3: There is a relationship between consumers' desires to pay for beach vacation at illegally built resorts and their desires to get a free public beach vacation at public beaches.

H4: There is a relationship between visiting public beaches and the level of beach services.

H5: There is a relationship between illegally built resorts and coastal development in Lebanon. 


\section{Data Analysis}

The Pearson's product moment correlational analysis which is a measure of strength of the linear association between two variables was used (Gravetter \& Wallnau, 2013). The bidirectional elimination stepwise regression analysis which removes or adds variables based on the $t$-test estimate of coefficient was used, "attending public beaches" was considered as the dependent variable, and all the other items as independent variables. The level of significance was set at $p \leq 0.05$ (Marascuilo \& Serlin, 1988).

\section{Results}

The total number of usable responses was $255(n=255)$. Respondents were $51 \%$ males, $41 \%$ college graduates, and $58 \%$ between the ages of $18-23$.

Of the respondents, $91.4 \%$ agreed to the fact that the Lebanese government should play an active role in the development of public beaches. The agreement on the statements in which local people should be involved in the development of public beaches reached a 79.6\%. When asked what would be the reason for not visiting public beaches, the responses varied among the individual social image (16.5\%), fear of being seen on a public beach (29.4\%), location of public beach (9.4\%), and absence of services (fresh water, umbrellas, shops, etc.) (31\%).

The Pearson correlation matrix was used to report the correlations among the different variables included in the questionnaire. It should be noted that only a significant correlation at the $p \leq 0.05$ level was included. Many of the variables were interrelated; however, the majorities were characterized by low correlation coefficient.

In this research, a number of regression models were run to measure the different effects on the dependent variable. The regression dependent variables were: public beaches attendance, involvement in public beach development, and opinion towards public beaches.

The first regression model considered respondents' socio-demographics as independent variables. None of the independent variables had any significant value. H1 was rejected, since there is no significant relationship between attending public beaches and the socio-demographic attributes of the respondents.

Since the objective of the study was to identify the factors that affect visiting or attending public beaches, the second regression model used the involvement variables as independent variables and public beach attendance as the dependent variable. The overall test proved to be significant. The involvement in developing public beaches has an overall significance of $p<0.01$, which indicates a relation with the opinion of attending public beaches regularly, thus it could be stated the $\mathrm{H} 2$ is accepted.

The stepwise regression analysis process used "attending/visiting" public beaches regularly as being the independent variable, and all the other items (excluding socio-demographic) being set as dependent variables. Results of the stepwise regression are presented in Table 2.

Table 2

Results of the Stepwise Regression Analysis

\begin{tabular}{lllll}
\hline Model & $R$ & $R$-square & Adjusted $R$ square & Std. error of the estimate \\
\hline 1 & $0.406(\mathrm{a})$ & 0.165 & 0.161 & 1.019 \\
2 & $0.520(\mathrm{~b})$ & 0.270 & 0.264 & 0.955 \\
3 & $0.563(\mathrm{c})$ & 0.317 & 0.309 & 0.925 \\
4 & $0.583(\mathrm{~d})$ & 0.340 & 0.329 & 0.912 \\
\hline
\end{tabular}


(Table 2 continued)

\begin{tabular}{lllll}
\hline Model & $R$ & $R$-square & Adjusted $R$ square & Std. error of the estimate \\
\hline 5 & $0.596(\mathrm{e})$ & 0.356 & 0.343 & 0.902 \\
6 & $0.607(\mathrm{f})$ & 0.368 & 0.353 & 0.896 \\
7 & $0.616(\mathrm{~g})$ & 0.380 & 0.362 & 0.889 \\
8 & $0.624(\mathrm{~h})$ & 0.390 & 0.37 & 0.883 \\
\hline
\end{tabular}

Notes. a predictors: (constant), preferences: public vs. private beaches; $b$ predictors: (constant), preferences: public vs. private beaches and development of public beaches; c predictors: (constant), preferences: public vs. private beaches, development of public beaches, and attracts more tourists; $d$ predictors: (constant), preferences: public vs. private beaches, development of public beaches, attracts more tourists, and well-planned public beaches in Lebanon; e predictors: (constant), preferences: public vs. private beaches, development of public beaches, attracts more tourists, well-planned public beaches in Lebanon, and creates job opportunities for locals; f predictors: (constant), preferences: public vs. private beaches, development of public beaches, attracts more tourists, well-planned public beaches in Lebanon, creates job opportunities for locals, and reason for not visiting public beaches; g predictors: (constant), preferences: public vs. private beaches, development of public beaches, attracts more tourists, well-planned public beaches in Lebanon, creates job opportunities for locals, reason for not visiting public beaches, and local people involvement in the development of public beaches; and h predictors: (constant), preferences: public vs. private beaches, development of public beaches, attracts more tourists, well-planned public beaches in Lebanon, creates job opportunities for locals, reason for not visiting public beaches, local people involvement in the development of public beaches, and family and friends' participation in activities related to public beaches.

The low $R$-square value is explained by the dependent variable in relation to the independent variables. All the values included were significant because of the nature of regression. The $R$-square value 0.39 means that $39 \%$ of the variations in the dependent variables are explained by the independent variables.

The generated table of coefficients gives a clear idea of the effects of the models included in the stepwise regressions and their effects on attending public beaches. It is important to note that the $t$-test delivered a $p \leq 0.01$ significance level for all the factors.

All the variables presented are significant at the $p \leq 0.01$ level. Responses to preferences concerning private and public beaches generated a $t$-value of -7.065 . This negative relationship between preferences and attending public beaches indicates that the more the respondents prefer to pay for visiting private beaches, the less likely they are ready to visit free public beaches. This negative relation is maintained throughout the analysis with values like 6.386 and -5.681 in the subsequent steps. One could conclude from this stepwise model that $\mathrm{H} 3$ is accepted, since a relation exists between respondents' acceptances of paid beach vacation at illegally built resorts vs. free vacation at public beach.

The relation between developing public beaches and visiting them is positive, and it is represented by the $t$-value of 6.025. This model is another indication that $\mathrm{H} 2$ is accepted, and it complements the previous analysis where only the statements of the involvement category of the questionnaire were set to be as independent variables. Another variable which was found to be significant and has a relation with attending public beaches is the family and friends' participation in beach-related activities, which proved once again that it has a positive relation with the dependent variable.

The "existence of well-planned public beaches in Lebanon" statement has a positive relation (2.939) with attending public beaches at the significance level of $p \leq 0.01$. This relation is confirmed and is considered as a main factor in accepting $\mathrm{H} 4$ which states that there is a relation between attending public beaches and the beach services. It suggests that the more public beaches are developed and the more services are available (fresh water showers, free tents, beach recliners, vending serves, clean ups, etc.), the more people are willing to attend and visit regularly. 
Reasons for not visiting public beaches include: image, peoples' socio-economic background, beach location, absence of facilities, and others. The positive relation (2.947) suggests that the more governments will work on reflecting a better image of public beaches and raising the level of services by choosing a good potential location and creating better facilities, the more people will be willing to attend public beaches regularly.

The results of the regression models question the low $R$-square value (0.39), nonetheless previous studies dealing with intentions (insurance, buying behavior, etc.) indicated that low $R$-squares are acceptable and it is usual to find such figures in other fields of business studies. The findings of this paper match Langford and Capella's (1994) previous study on personal automobile insurance shopping intentions, which suggested that the predictor variables in the model could not explain most of the variance in the criterion variable. The explanation for these results ranged from omitting some important variables to the inclusion of substantial randomness in the insured's intentions and the difficulty in predicting shopping intentions (Langford \& Capella, 1994). Since this research is concerned with intentions of the respondents to visit public beaches regularly, Langford and Capella's (1994) findings match those of this study.

Since resorts and other types of industrial complexes are illegally occupying parts of the coast without paying taxes or fees, it is impossible to create a coastal development plan. Solidaire, a company responsible for the planning and development of downtown Beirut, pays the Lebanese government fees for using the land. In an area where the land value is considered to be very high compared with other areas in the country, Solidaire is paying an amount of LL 2,500 per meter per year where it should be paying at least $6 \%$ of the land value it develops its project on. The decree offers fees ranging from LL 750,000 per square to LL 1 million in that area (Lakkis, 2012).

H5 is accepted, since there is a relationship between legal framework and coastal development, meaning that if the illegal status of the resorts and industrial complexes on the Lebanese coast were to be legalized, a well-planned coastal development initiative will take place and the government would be able to plan and finance future public beach development initiatives.

\section{Conclusions and Recommendations}

Four out of the five hypotheses were accepted during the analysis process. A relationship exists between attending public beaches and beach goers' opinion and local community involvement in beach development. The study concludes that the development of public beaches is undoubtedly correlated to the presence of the illegally existing resorts on the Lebanese coast. Once illegal resorts gain a legal status and start paying taxes, generated revenues will be reinvested in the development of public beaches. If illegal resorts were to be legalized, local governments and communities may have free access to the developed public beaches.

The process of reclaiming Lebanon coastline and developing it is not a short-term simple process, it needs long-term planning which requires the involvement of different stakeholders. Studying previous management practices in other countries presents a clear idea of the steps that should be taken and the plans that are followed. United States, Canada, and Spain have implemented similar programs and they are very effective. Like all the other cost reclamation initiatives, follow-up studies about program implementation and goal attainment should be undertaken.

The study of Pogue and Lee (1999), which outlined the different steps that need to be taken in clearing out the land for coastal development, can be adopted. Lebanon does not have the economic means or the technical 
know-how to implement the steps the same way they did in the United States and in other countries. Programs like BOT, built operate transfer, are initiatives funded by the private sector that can help serve the purpose. The involvement of private parties in the acquisition phase is essential, because the Lebanese government has allocated a small ratio of its budget to the tourism industry (Bakhos, 2007).

Although public beaches were not a priority for the Canadian government when developing the coast, they allocated two of the four parts they developed in the coastal panning to the recreation and public beaches concept (Yarnell, 1999). Similarly, when the Spanish authorities created a plan to recover possessions of coastal properties, it had to remove $23 \%$ of the buildings occupying the coast and $42 \%$ had to be relocated (MOPU, 1998; as cited in Malvarez Gracia, Pollard, \& Rodriguez, 2004). The law was applied without exceptions or preferential treatments. Likewise, Lebanese legislators should be fair when applying the law. No exemptions should be granted. The government should assume control over Lebanon's coastline and should make sure that the public is granted free access to sandy beaches.

Locals and tourists admire the beauty of the Lebanese coast and believe that its visitors should be able to freely access any public beach. During the distribution of the questionnaire, numerous respondents commented verbally that if public beaches in Lebanon resembled public beaches in Greece, Cyprus, and Turkey, they will visit more frequently. So what will it take the Lebanese government to implement a coastal development plan that would allow our local beaches to compete with neighboring countries? After all, the above listed countries share the same Mediterranean coast with Lebanon.

Only the government has the answers to these questions. Legislators, consumer advocate groups, and environmentalists should collaborate to develop free public beach access initiative. The initiative should be easy to implement and should support government's actions to reclaim public beaches from those who have built and benefited illegally from the Lebanese coastline.

\section{References}

Aboudehn. (2007). War in Lebanon the biggest environmental catastrophe in the history of the country. Retrieved from http://www.oilspilllebanon.org

Assaf, T. (2009). Lebanese coastal zone. Ministry of Public Works and Transport.

Bakhos, A. (2007). Interview with Patrick El Meouchi.

Gravetter, F. J., \& Wallnau, L. B. (2013). Statistics for the behavioral sciences. New York, N.Y.: West Publishing Company.

Lakkis, H. (2012, August 7). Cabinet to study new coastal land taxes. The Daily Star.

Langford, B. E., \& Capella, L. M. (1994). A model of personal automobile insurance shopping intentions (PAPSI). The Journal of Insurance Issues, 17(2), 1-22.

Lebanese Ministry of Tourism. (2007). Lebanon advisor. Beirut: Pan Arab Publishers.

Malvarez Gracia, G., Pollard, J., \& Rodriguez, R. D. (2004). The planning and practice of coastal zone management in southern Spain. In Coastal mass tourism diversification and sustainable development in southern Europe (pp. 200-219). Channel View Publications.

Marascuilo, L., \& Serlin, R. (1988). Statistical methods for the social and behavioral sciences. New York, N.Y.: W. H. Freeman and Company.

Pogue, P., \& Lee, V. (1999). Providing public access to the shore: The role of coastal zone management programs. Coastal Management, 27(2-3), 219-237.

Yarnell, P. (1999). Port administration and integrated coastal management under the Canada Marine Act in Vancouver, British Columbia, Canada. Coastal Management, 27, 343-354.

Zbeeb, M. (2012a, December 10). Where to find Lebanon's worst seafront violations. Alakhbar.

Zbeeb, M. (2012b, December 11). An industrial coast for Mount Lebanon. Alakhbar. 